\title{
A Case Report: Management of Mukhadushika (Acne Vulgaris) with Ayurveda
}

\author{
Case Report
}

\section{Jetal Gevariya ${ }^{*}$, Sangita Kamaliya², Vaghela D B ${ }^{3}$}

1. PG. Scholar, 2. Ph.D Scholar, 3. I/C HOD \& Associate Professor;

Department of Shalakya Tantra, ITRA, Jamnagar, Gujarat, India.

\begin{abstract}
Background: Acne vulgaris is a chronic inflammatory condition of skin in youth. In Ayurveda, acne has been elaborated as one of the Kshudra Rogas. In this modern era, this is a burning problem in the adolescence. Symptoms of Mukhadushika show close resemblance with bacterial infection and inflammatory factors of acne. In Ayurveda, it can be correlated with Mukhadushika. Vitiation of Kapha Dosha, Vata Dosha and Rakta Dhatu lead to development of Mukhadushika. Methods: A 25-year-old patient presented with complaint of Pidaka (Papules and putules) on face and neck including Medogarbhatva (filling material), Todavat peeda (Piercing pain), Daha (Burning sensation), Srava (Discharge) and Kandu (itching) associated with irregular bowel and recurrent comedones, since 1 year. Management done with OPD based treatment. Here in this case report treatment chosen was i.e. Avipattikar churna orally and Lodhradi lepa for external application along with Baspa Sweda (take a steam) for 1 month followed by Kumkumadi Taila for next 15 days. Result: There was marked improvement in symptoms Pidaka (Papules and pustules) on face and neck including Medogarbhatva (filling material or nodules), Todavat peeda (Piercing pain), Daha (Burning sensation), Srava (Discharge) and Kandu (itching) associated with irregular bowel and recurrent comedone with the treatment of 1.5 month. Conclusion: Significant result was observed with this treatment protocol in the management of Mukhadushika (Acne vulgaris).
\end{abstract}

Key Words: Ayurveda, Acne vulgaris, Mukhadushika, Pimples.

\section{Introduction}

Acne vulgaris, a chronic inflammatory disorder in adolescents consists of the pilosebaceous follicles, characterized by comedones, papules, pustules, cysts, nodules and often scars, chiefly on face, neck etc (1). It is a skin condition that occurs due to the clogging of oil glands (sebaceous glands) of the skin (2). The oil (sebum) that normally lubricates the skin gets trapped in blocked oil ducts. Hormone changes during the teenage cause the body to make more of this oily substance (sebum), thus are clogging the follicles. Bacteria can get inside the follicle or oil gland and cause redness, swelling, and pus. It is one of the most common dermatologic condition that affects nearly everyone at some point in their lifetime. Adult acne is becoming increasingly popular. It is a disease of the skin which can be painful for those suffering from moderate to severe acne (3). Acne vulgaris mostly affects the areas of skin with the densest population of sebaceous follicles these areas include the face, the upper part of the chest, and the back (4).The cause of acne is unknown. It is presumed to be activated by androgens

* Corresponding Author:

\section{Jetal Gevariya}

PG Scholar,

Department of Shalakya Tantra,

ITRA, Jamnagar,

Gujarat, India.

Email Id: dr.jetalgevariya007@gmail.com
Once thought as a condition only affecting teenagers, prevalence in adulthood has been increasing, especially in women 25 years of age and older (5). The earliest abnormalities in acne are:

- Increased sebum production due to which the skin looks greasy(seborrhea)

- Formation of horny plugs (comedone)

In Ayurveda, it can be correlate with Mukhadushika which is explained by Acharya Sushruta under Kshudra Rogas (6) and is considered as swatantra vyadhi in the ayurvedic literature. It is characterized by Shalmali Kantaka Sadrusha Pidikas on face. These Pidikas destroy the beauty of the face and cause disfigurement of the face therefore they are also called as "Mukhadushika" 7). Face is the index of mind and a beauty. Cosmetic impact of deformities on the face is far reaching and in order to improve the complexion various Soundarya Vardhak Dravyas were used in older times as similar to today's scenario. This created an interest to study the various aspects of the disease. In Ayurveda, mainly two types of Chikitsa (treatments) have been used to treat acne i.e. Shodhana (purification of body) and Shamana (conservative treatment by oral and topical medicines). Shodhana includes Vaman and Nasya, whereas Shamana includes Lepa, Upanah and Kshara application. Lepa procedure is described in many Samhita, it harnesses the effect of Mukhadushika as well as increase the Mukhakanti. In this case study, management of Mukhadushika (Acne vulgaris) has been elaborated with Shamana Chikitsa. 


\section{Case Report}

A 25-years-old patient presented with complaint of Pidaka (Papules and putules) on face and neck including Medogarbhatva (filling material), Todavat peeda (Piercing pain), Daha (Burning sensation), Srava (Discharge), Kandu (itching) associated with irregular bowel and recurrent comedones, since 2 year at Shalakya Tantra (ENT) OPD of IPGT \& RA hospital, GAU, Jamnagar on date 18/8/2020. Same problem was arising before three years. Patient have apparently good and healthy skin before 2 years. Gradually patient suffered with Comedones, Red papules (Rakta Pidaka), Pustules, Nodules around cheek and neck. For that patient approached contemporary medical sciences for treatment. But patient's complaints did not get satisfactory result. So patient came to our hospital, and patient was treated with Avipattikar churna orally and Lodhradi lepa for external application along with Baspa Sweda (steam therapy) for 1 month followed by Kumkumadi Tailm for 15 days.

- Aggravating Factors: Exposure to dust and intake of spicy diet.

- Past History: No other past history was noted according to patient statement.

- History of Allergy: Not any allergic history.

- Medical History: Patient not suffering from any systemic disease i.e. HTN/DM/IHD.

- Current Medication: Patient was using Clindamycin cream with only temporary relief in blackheads.

- Family History: No any relevant family history.

- Personal History:

- Diet: vegetarian, Appetite: moderate, Bowel: irregular (2 time/ day), Micturition: normal (5-6 time/day), Sleep: Disturbed, Addiction: tea (2 times/day)

- Occupational History:

- Architecture designing Hours of working: Day: 6 hours, Nature of work: Sedentary

- General Examination:

- Vital Data: Pulse: 78/min; R/R: 18/min; BP: 110/70; Temp: $98^{\circ} \mathrm{F}$, Pallor: Absent, Weight: 50 $\mathrm{kg}$, Height: $165 \mathrm{~cm}$

\section{$\mathbf{O} / \mathbf{E}$ :}

Table 1: Assessment Scale (comprehensive acne vulgaris severity scale - CASS)

\begin{tabular}{|c|c|c|}
\hline Grade & Severity & Description \\
\hline 0 & $\begin{array}{l}\text { Clear } \\
\text { skin }\end{array}$ & $\begin{array}{l}\text { No lesions to barely noticeable } \\
\text { ones, very few scattered } \\
\text { comedones and papules }\end{array}$ \\
\hline 1 & $\begin{array}{l}\text { Almost } \\
\text { clear skin }\end{array}$ & $\begin{array}{l}\text { Hardly visible from } 2.5 \text { meters } \\
\text { a w a y, a few s c a t t e re d } \\
\text { comedones, small papules, very } \\
\text { few pustules }\end{array}$ \\
\hline 2 & Mild & $\begin{array}{l}\text { Easily recognizable, less than } \\
\text { half of the affected area is } \\
\text { involved, many small } \\
\text { comedones, papules and } \\
\text { pustules }\end{array}$ \\
\hline
\end{tabular}

More than half of the affected area is involved, numerous comedones, papules and pustules

Entire area is involved, covered with comedones, numerous 4 Severe papules and pustules, very few nodules and cysts

\begin{tabular}{l|l|l}
5 & $\begin{array}{l}\text { Very } \\
\text { severe }\end{array}$ & $\begin{array}{l}\text { Highly inflammatory acne } \\
\text { covering the affected area, } \\
\text { nodules and cysts present }\end{array}$
\end{tabular}

O/E: Assessment was done on the base of comprehensive acne vulgaris severity scale - CASS before treatment. Patient was assessed and examined from that concluded that the patient was suffering from Grade 4 acne vulgaris with pustules, papules, comedones, very few nodules were observed over cheek, chin and neck region. (Image1, 2)

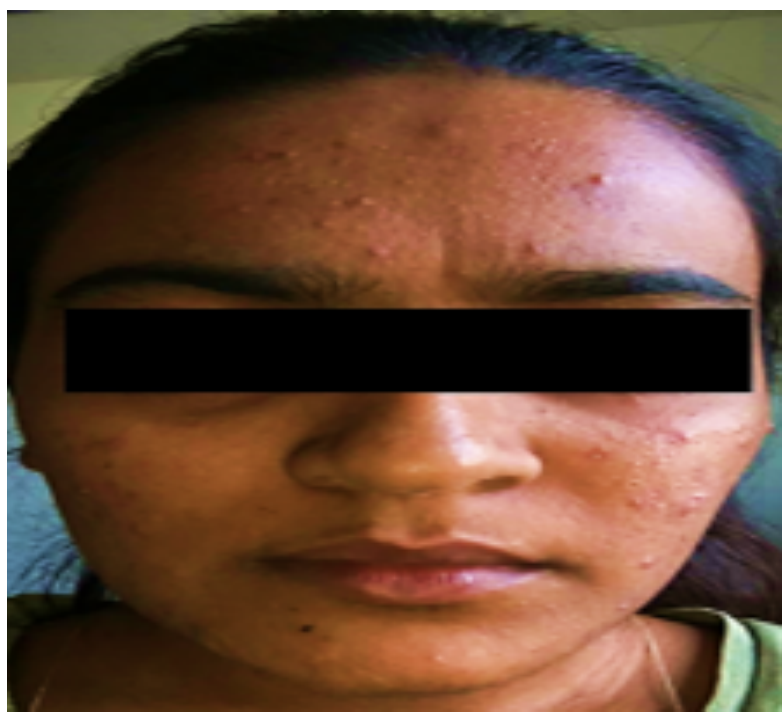

Image 1: Before treatment acne vulgaris Front view of face

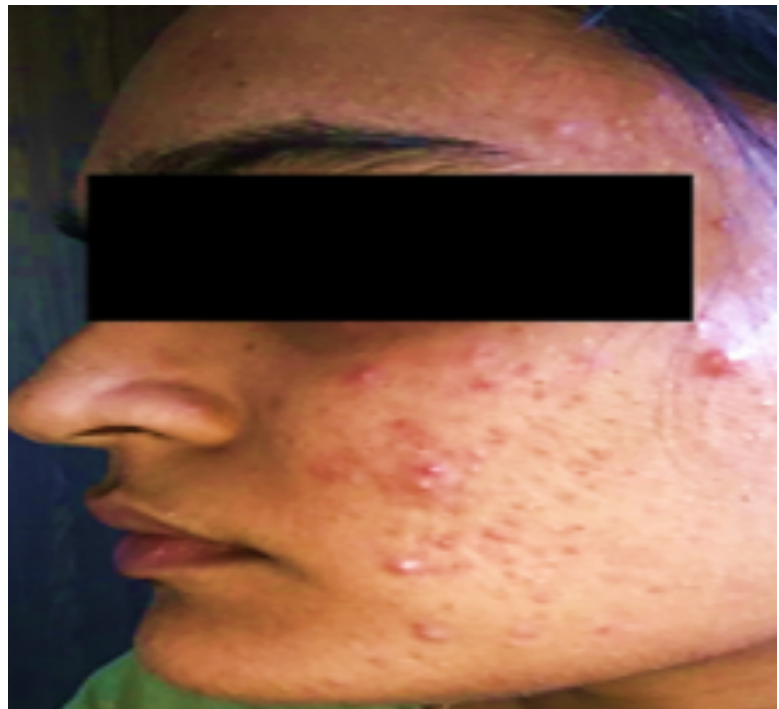

Image 2: Before treatment acne vulgaris lateral view of face 


\section{Therapeutic Intervention: Table no. 2}

Table 2: Treatment protocol

\begin{tabular}{|c|c|c|c|}
\hline Drug & Dose & $\begin{array}{l}\text { Root of } \\
\text { administration }\end{array}$ & Duration \\
\hline $\begin{array}{l}\text { Avipattikar } \\
\text { churna }\end{array}$ & $\begin{array}{l}3 \text { gm } 2 \\
\text { time per } \\
\text { day with } \\
\text { water } \\
\text { before } \\
\text { meal }\end{array}$ & Orally & 1 month \\
\hline $\begin{array}{l}\text { Lodhra } \\
\text { Vacha } \\
\text { Kushtha } \\
\text { Chandana } \\
\text { Masur Dala } \\
\text { Churna } \\
\text { Haridra }\end{array}$ & $\begin{array}{l}8 \text { gm for } \\
\text { external } \\
\text { applicati } \\
\text { on on } \\
\text { acne } \\
\text { with } \\
\text { water }\end{array}$ & $\begin{array}{l}\text { External } \\
\text { application }\end{array}$ & 1 month \\
\hline $\begin{array}{l}\text { Kumkumadi } \\
\text { Tailam }\end{array}$ & SOS & $\begin{array}{l}\text { External } \\
\text { application }\end{array}$ & $\begin{array}{l}\text { After } 1 \\
\text { month for } \\
15 \text { days }\end{array}$ \\
\hline
\end{tabular}

Pathya-Apathya: Table no. 3

Table 3: Pathya-Apathya

$$
\text { Do's Don'ts }
$$

- Cover face with clean - Avoid spicy food, cloth while exposer to bread, bakery items, dust and smoky areas. ice cream, cold drinks,

- Take steam inhalation chocolates, fast food, through mouth two fermented food items, times a day with plain any color chemical water containing items.

- Intake of lukewarm - Avoid tea and coffee. water for the whole day as a routine

\section{Results}

On the first follow up i.e. on $15^{\text {th }}$ day of treatment patient told mild relieved in the symptoms. She felt moderate relief in pustules on face and neck. Patient felt mild relief in pain, burning and itching. There was marked relief in pus discharge and she felt less in oily skin. Her digestion power was improved and relief in constipation. There was no relief in papules.

[Image: 3,4]

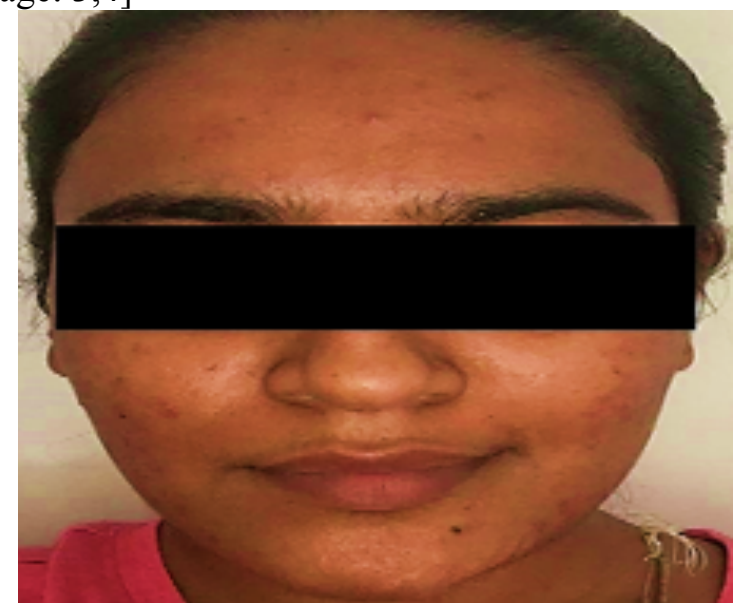

Image: 3 1st follow up $15^{\text {th }}$ day Relief in pustules

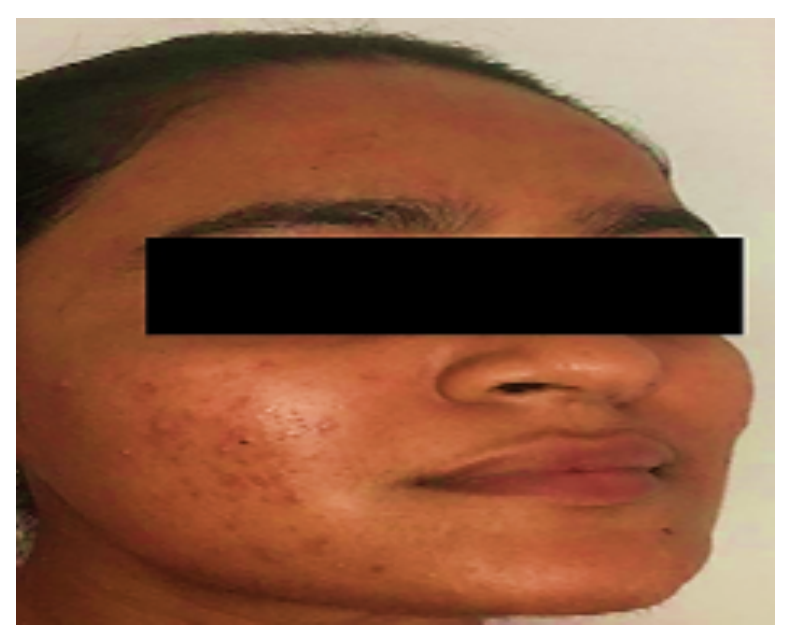

Image: 4 1st follow up lateral view of face Shows that there is papules left behind

On the second follow up i.e. on $30^{\text {th }}$ day of treatment patient relief from symptoms. In all the remnant symptoms patient was feeling marked relief. Also relief in papules. There was only slight papules remain left and there was totally relief in pustules. There was not any pus discharge and pain, burning still she felt mild itching on cheek and neck. On examination can see comedones in place of pustules and papules. [Image: 5,6]

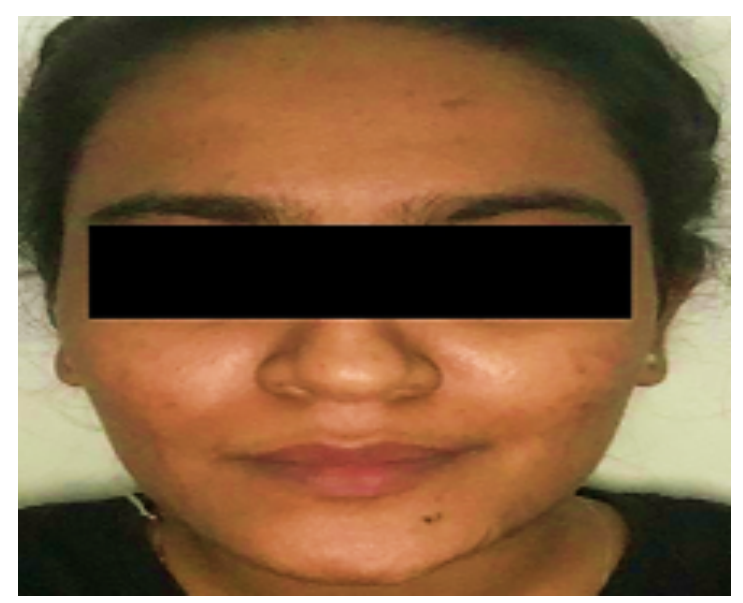

Image: $52^{\text {nd }}$ follow up $30^{\text {th }}$ day Relief in papules

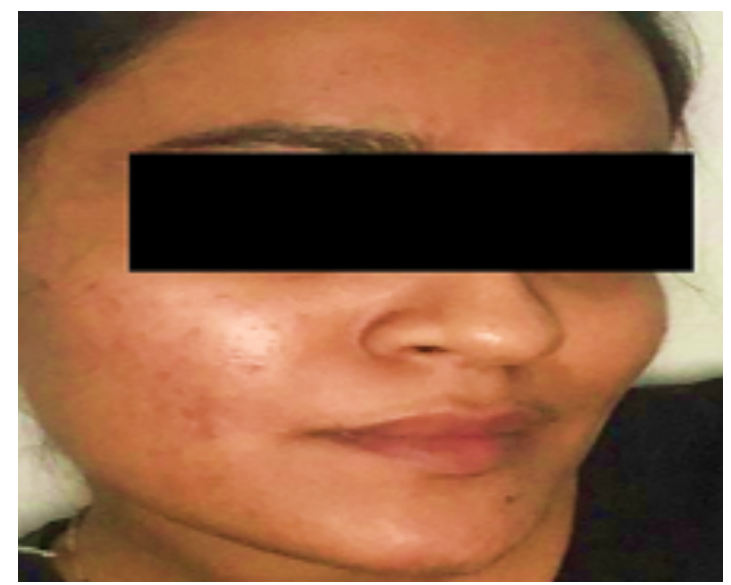

Image: $62^{\text {nd }}$ follow up lateral view shows comedones, black spots left behind 
Jetal Gevariya et.al., A Case Report: Management of Mukhadushika (Acne Vulgaris) with Ayurveda

On the third follow up i.e. on $45^{\text {st }}$ day of treatment patient's face was clean. There was not papules and comedones left behind. Completely relieved from pain, itching and discharge. Almost relief in dysphagia. Patient was quite satisfied since patient was completely relieved from disease. There was normal, glowing and shiny skin of face and neck. [Image: 7,8]

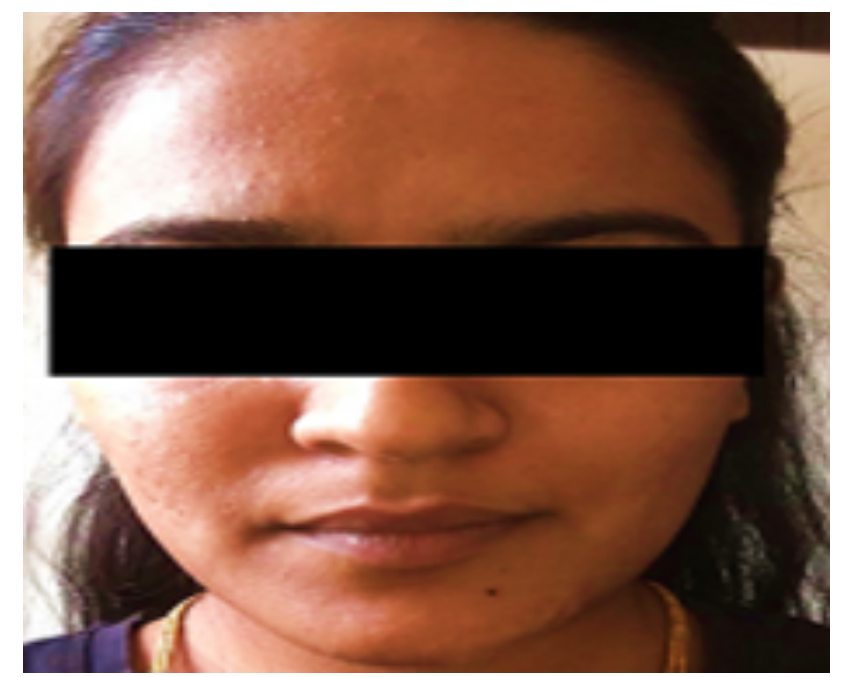

Image: 7 After treatment Relived all signs Symptoms Front view of face

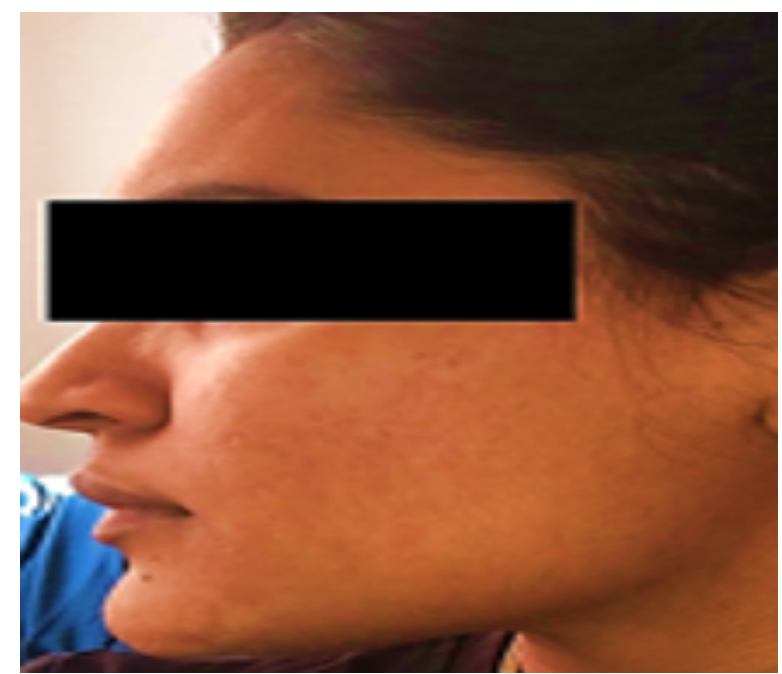

Image: 8 after treatment relived all signs lateral view of face

After completion of 2 month skin was normal, glowing and shiny of Grade - 0 acne scale. And no any pain, burning, itching, discharge was present not any pustules, papules or comedones.

\section{Discussion}

Mukhadushika (Acne Vulgaris) is mostly seen in adolescence age group i.e. in Dhatuvivardhamana Awathstha 16-30yrs, specially the starting period of functional state of Shukradhatu (Abhivyakti and Vridhi). This is also the age of predominance of Pitta and Shukra Dhatu, along with consumption of unbalanced food, alternate mode of lifestyle, which causes the vitiation of Dosha and Doshya (8). So, the patient was advised for Nidanaparivarjana. Most of the Acharya has mentioned in Vaman, Virechan, Nasya, Raktamokshan for Mukhadushika along with Samana Chikitsa and local application.

Steam therapy can help minor pore blockages and blackheads be extracted. Steam therapy soften blemishes and make them easier to extract but steaming alone won't clear up acne (9).

Avipattikar Churna was prescribed to the patient for 1 month. Avipattikar Churna contains, Zingiber officinalale Roscoe. (Shunthi), Piper longum Linn. (Pippali), Piper nigrum Linn. (Maricha), Terminalia chebula Retz. (Haritaki), Terminalia belarica Retz. (Vibhitaki), Emblica officinalis Gaertn. (Amlaki), Elettaria cardamomum Maton. (Ela), Cinnamomum tamala Nees\&Eburm. (Tejpatra), Cyperus rotundus R.br. (Nagarmotha), salt (Vidlavana), Embilia ribes Linn. (Vayvidanga) all in equal parts with eleven parts of Syzygium aromaticum Linn. (Lavanga), forty four parts of Trivrit root and sixty six parts of Sita (10). Among that Sunthi, Maricha and Pipali Due to its katu rasa it also reduces Medo Dhatu Ashrit Kapha and Kleda in the body and it is also Srotoshodhaka thus helps in pacifying Vatakapha Vikara. Due to Madhur, Tikta, Kashaya Rasa it is vitiated Pitta Shamaka, due to Katu, Tikta Kashaya Rasa it is vitiated Kapha Shamaka and due to Amla, Madhura Rasa it is vitiated Vata Shamaka. Mainly it is act on vitiated Vata and it is Vata Anulomaka. Bibhitaki is Chedaniya (Shleshmhara) in Prabhava. It is act on vitiated Kapha and Vata Dosha. Due to Ruksha, Laghu, Kashaya Rasa properties it pacifies vitiated Kapha, due to Madhura Rasa pacifies vitiated Pitta, and its Ushna property helps in pacifying vitiated Vata (11). Amalaki is Dahprashamaka and Anulomaka (12). Ela is also Dahaprashamaka in nature. Vayvidanga is Ushna in potency thus it is Kapha Vata Shamaka. It is Jantughna in nature thus mentioned as best Krimighna drug (13). Nishotha is Sukhvirechiniye in Prabhava, Bhedana and Rechana in properties. It reduces swelling as mentioned as Shothahara in texts. Vidlavana is Vatanulomaniya. Lvanga is Chedniya in Prabhava, thus play a beneficial role in Chedan of Kapha from the body. Snigdha guna in it makes it Vatanulomaka and Shoola Prashmana. Sita is rich in Madhur Rasa thus pacifies vitiated Pitta-Rakta Dosha and it is Dahprasamaka. Thus, most of the Dravyas of Avipattikar churna are Kapha-Vatahara and Anulomaka in nature.

Lepas (pastes) act as Astringent, Antiinflammatory and Antibacterial agents. Lepas not only treat the acne but also increase the skin complexion.

In Ayurveda, Lepas have been especially advised for application on oily skin whereas Tailas (oils) have been advised for dry type of skin. Lodhradi Lepa was selected for external application.

All the drugs except Lodhra are Ushna Veerya so they are Vata Kapha Shamaka and Sheeta Veerya of Lodhra pacifies the Dushita Rakta. Vacha has Lekhana property so it helps in Subsiding Medogarbha Pidika. Thus, the combination of drugs helps in reversing the pathogenesis of Mukhadushika (Acne Vulgaris). 


\section{Conclusion}

This single case report concludes that Ayurvedic management with Avipattikar churna orally and Lodhradi lepa for external application along with Baspa Sweda (take a steam) for 1 month followed by Kumkumadi Taila for next 15 days offers excellent result in the treatment Mukhadushika (Acne vulgaris). This protocol should be evaluated in more number of patients for its scientific validation.

\section{References}

1. Lalla JK, Nandedkar SY, Paranjape MH, Talreja NB (2001) Clinical trials of Ayurvedic formulations in the treatment of Acne vulgaris. J Ethnopharmacol78: 99-102.

2. Diane T, John S (2003), Fitzpatrick's dermatology in general medicine. Diseases of the sebaceous glands. 6: 34-56

3. Krowchuk DP, Stancin T, Keskinen R, Walker R (1991) the psychosocial effects of Acne on adolescents. Pediatric Dermatol 8: 332-338.

4. Cordain L, Lindeberg S, Hurtado M, Hill K, Eaton SB, et al. (2002) Acne vulgaris: a disease of Western civilization. Arch Dermatol 135: 1584-1590.
5. Decker A, Graber EM. J Clin Aesthetic Dermatol. Over-the-counter acne treatments: a review. 2012;5(5):32-40.

6. Sushruta, Sushruta Samhita Vaidya, Sutra sthana, 46/525, Edited by Yadavji Trikamji Acharya, 9th ed. Varanasi: Chaukhambha Orientalia; 2007

7. Bramhashankar Mishra, Bhavaprakasha Vidyotini Tika, Madhya Khanda61/31, Chaukhambha Sanskrit Sansthana, Varanasi, 11 edition, 2004

8. Rathod M., Kamath S., A clinical study to evaluate the efficacy of Jalaukawacharan and Sarivadyasava in Yuvanpidaka; IRJP, 2012: 3(7).

9. https://www.verywellhealth.com/will-a-facialsteam-clear-acne-15513

10. Kaviraj shree Ambikadatt Sastri, Bhiashajyaratnawali 56 th chapter, Amlapittarogadhikara; Varanasi, India: Chaukhamba Surbharti Prakashan, 2016.

11. Sharma, Priyavritta (Rep.ed) Dravyaguna vigyana dwitiya bhaga; Varanasi, Delhi, India: Chaukhamba Bharti Academy, 2006.

12. Sharma, Priyavritta (Rep.ed) Dravyaguna vigyana dwitiye bhaga; Varanasi, Delhi, India: Chaukhamba Bharti Academy, 2006.

13. Sharma, Priyavritta (Rep.ed) Dravyaguna vigyana dwitiye bhaga; Varanasi, Delhi, India: Chaukhamba Bharti Academy, 2006. 